\title{
Cancer Patient Satisfaction and Perception of Chemotherapy Services during COVID-19 Pandemic in Central Java, Indonesia
}

\author{
Yan Wisnu Prajoko ${ }^{1}$, Tommy Supit ${ }^{2}$
}

${ }^{1}$ Department of Oncologic Surgery, Faculty of Medicine Diponegoro University, Dr. Kariadi General Hospital, Semarang, Indonesia. ${ }^{2}$ Department of Surgery, Faculty of Medicine Diponegoro University, Dr. Kariadi General Hospital, Semarang, Indonesia.

\begin{abstract}
Background: The COVID-19 pandemic affects all healthcare services, including cancer care. Consequently, our institution implemented several changes in accordance with the National guidelines for managing COVID-19 transmission. However, the patients' perception of such changes is unknown. The objective of this study is to explore the knowledge of cancer patients on COVID-19, their perceptions towards the changes in oncology service, and to identify key elements that contribute to their level of anxiety or comfort. Methods: Written questionnaires were given out to cancer patients indicated or undergoing chemotherapy between 23rd June and 3rd July 2020 in a tertiary referral hospital. Data collection was performed 75 days after the implementation of hospital and oncology services changes in response to COVID-19. Results: A total of 221 cancer patients participated in this study. The majority of patients possess adequate knowledge and practice appropriate preventive actions. They expressed a positive attitude towards the changes in hospital policies and contented with the consistency of chemotherapy services. The television and internet (social media, communication apps) were the main sources of information for the patient. Conclusion: Our institution managed to maintain the consistency of chemotherapy services, despite the implementation of several changes in hospital and treatment policies. With adequate education, patients can remain content and express a positive attitude towards the changes in their treatment experience. Both health care personnel and policymakers should consistently be updated with the continuous surge of publications regarding COVID-19 and adjust their decisions with the best evidence-based practice.
\end{abstract}

Keywords: oncology- awareness- knowledge- coronavirus- health care

Asian Pac J Cancer Care, 5 (Suppl 1), 43-50

\section{Introduction}

The Indonesian authority declared the first confirmed case of coronavirus disease 2019 (COVID-19) positive patient on $2^{\text {nd }}$ March 2020, a month after the WHO declared the COVID-19 outbreak a public health emergency [1-2]. By Mid July, 80.094 Indonesians were infected with a mortality rate of $4.74 \%$ [3]. This highly infectious disease has impacted all aspects of daily life and healthcare services, including cancer care. The delivery of cancer care during the pandemic poses immense challenges, considering the competing risks of mortality related to cancer or the infection of complications related to the SARS-CoV-2 [4]. Early shortage of personal protective equipment (PPE), limited isolation facilities, and lack of testing further complicate
Submission Date: 07/16/2020Ａcceptance Date: 08/15/2020

Corresponding Author:

Dr. Yan Wisnu Prajoko

Department of Oncologic Surgery, Faculty of Medicine Diponegoro University, Dr. Kariadi General Hospital, Semarang, Indonesia.

Email: yanprojoko7519@gmail.com 
greater psychological stress because of postponed treatment and isolation on top of their inherent disease. Considering the novelty of this disease, there is a paucity of information and experience of cancer management during the pandemic. The objective of this study is to explore cancer patients' perception of oncology service amid the pandemic and to identify key elements that contribute to their level of anxiety or comfort. Obtaining such information may aid policymakers in decisionmaking to create strategies for ensuring better cancer care during the outbreak.

\section{Materials and Methods}

\section{Questionnaire}

This qualitative descriptive research aimed to gain information of cancer patient perception on cancer service during the pandemic. Eligible participants were given out a set of questionnaires to be completed during their visit or treatment in our institution. A semistructured questionnaire was developed by a committee of oncologist, institutional COVID-19 task force and approved by the governing Research Ethics Committee. The questionnaire is comprised of 30 multiple-choice questions divided into 2 parts. The first fifteen questions evaluate the subject's general knowledge of COVID-19 pandemic; awareness on the severity of the outbreak, preventive practices undertaken, and how pandemic affects their daily activities and disease. The rest of the questions explore the subject's experience, level of anxiety, and fear of undergoing chemotherapy. This part also evaluates the quality of healthcare service during the outbreak and allows the respondents to give inputs on what could be implemented to improve it. The questionnaire was created in Indonesian. The English version as seen in Table 2 and Table 3 were translated from Indonesian to English by two different researchers and then reconciled by a third reviewer for the best-corrected version.

\section{Study participants, data collection and analysis}

Participants included for this study were all cancer patients indicated for chemotherapy (prior, undergoing, or post) in Dr. Kariadi General Hospital, Semarang, Indonesia. Patients who refused to participate or considered to be clinically unfit were excluded. Two researchers unaffiliated with our institution performed data collection within $22^{\text {nd }}$ June 2020 until $3^{\text {rd }}$ July 2020; 75 days after the implementation of hospital and treatment policy changes on $9^{\text {th }}$ April 2020. Using the conveniencesampling method, all subjects were recruited while waiting in the outpatient oncology clinic or undergoing chemotherapy in the ward. Participant's confidentiality was ensured and that their response will not in any way affect the chemotherapy service. Every subject was given an unlimited amount of time to complete the questionnaire that was collected within the same day.

A family member or the researcher was allowed to assist participants in filling the form. Uncompleted questionnaires were excluded from the analysis. Ethical approval was granted by the hospital Ethics Committee
(No.543/EC/KEPK-RSDK.2020). Data were tabulated and analyzed using Microsoft Excel for Mac 2011 Version 14.4.1 (Microsoft Corporation, Washington, United States). Continuous variables are presented as total number (n) and percentage (\%) unless stated otherwise.

\section{Results}

A significant majority of the 221 participants in this study were Javanese females diagnosed with breast cancer with below than average level of income. The patients' demographic data are presented in Table 1. The coronavirus outbreak disrupted the daily activities of almost all patients

Table 1. Patient Demographics

\begin{tabular}{|c|c|c|}
\hline Patient demographics & $\mathrm{n}$ & $\%$ \\
\hline Total & 221 & 100,0 \\
\hline Female & 183 & 82,8 \\
\hline Age (years old $)^{\mathrm{a}}$ & $49.2 ; 50 ; 20-82$ & \\
\hline No. household member ${ }^{\mathrm{a}}$ & $3.8 ; 4 ; 1-10$ & \\
\hline Married & 201 & 91,0 \\
\hline \multicolumn{3}{|l|}{ Ethnicity } \\
\hline Javanese & 214 & 96,8 \\
\hline Chinese & 3 & 1,4 \\
\hline Betawi & 1 & 0,5 \\
\hline Dayak & 1 & 0,5 \\
\hline Malay & 1 & 0,5 \\
\hline \multicolumn{3}{|l|}{ Level of education } \\
\hline No formal education & 12 & 5,4 \\
\hline Elementary & 50 & 22,6 \\
\hline Middle & 47 & 21,3 \\
\hline High & 61 & 27,6 \\
\hline College and above & 51 & 23,1 \\
\hline \multicolumn{3}{|l|}{ Level of monthy income ${ }^{b}$} \\
\hline Below average & 144 & 65,2 \\
\hline Average & 72 & 32,6 \\
\hline Above average & 5 & 2,3 \\
\hline \multicolumn{3}{|l|}{ Cancer diagnosis } \\
\hline Breast & 131 & 59,3 \\
\hline Gynecologic & 15 & 6,8 \\
\hline Hematology & 7 & 3,2 \\
\hline Colorectal & 8 & 3,6 \\
\hline Head and Neck & 31 & 14,0 \\
\hline Urology & 5 & 2,3 \\
\hline Lung & 5 & 2,3 \\
\hline Skin & 1 & 0,5 \\
\hline Lymphoma & 14 & 6,3 \\
\hline Sarcoma & 4 & 1,8 \\
\hline \multicolumn{3}{|l|}{ No. of chemotherapy } \\
\hline$<5$ & 81 & 36,7 \\
\hline 5 to 20 & 125 & 56,6 \\
\hline$>20$ & 15 & 6,8 \\
\hline
\end{tabular}

aData presented as mean, median, and minimum-maximum respectively ${ }^{b}$ Below average: $<3$ million Indonesian Rupiah (IDR), average 3-15 million IDR, above average $>15$ million IDR 
Table 2. General Knowledge and Awareness of COVID-19

\begin{tabular}{|c|c|c|c|}
\hline Questions & Answer & $\mathrm{n}$ & $\%$ \\
\hline \multirow[t]{3}{*}{ Q1. Are you worried about being infected by the Corona virus? } & Very worried & 65 & 29,4 \\
\hline & Worried & 106 & 48,0 \\
\hline & Not Worry & 50 & 22,6 \\
\hline \multirow[t]{3}{*}{ Q2. Are you or have you been infected with Corona virus? } & Yes & 0 & 0,0 \\
\hline & No & 179 & 81,0 \\
\hline & Do not know & 42 & 19,0 \\
\hline \multirow[t]{2}{*}{ Q3. If you answer Yes or No above, have you undergone a Corona examination? } & Yes & 16 & 7,2 \\
\hline & No & 205 & 92,8 \\
\hline \multirow[t]{4}{*}{ Q4. Is your daily activities disrupted since the pandemic began? } & Very & 57 & 25,8 \\
\hline & Yes & 85 & 38,5 \\
\hline & A little & 77 & 34,8 \\
\hline & Not at all & 2 & 0,9 \\
\hline \multirow[t]{2}{*}{ Q5. Have you been staying at home and avoid social events since the outbreak? } & Yes & 210 & 95,0 \\
\hline & No & 11 & 5,0 \\
\hline \multirow[t]{2}{*}{ Q6. Have you been keeping a safe distance of two meters from other people? } & Yes & 215 & 97,3 \\
\hline & No & 6 & 2,7 \\
\hline \multirow[t]{2}{*}{ Q7. Did you wash your hands more often since the outbreak? } & Yes & 219 & 99,1 \\
\hline & No & 2 & 0,9 \\
\hline \multirow[t]{2}{*}{ Q8. Have you been wearing a mask when your leave the house or meet other people? } & Yes & 219 & 99,1 \\
\hline & No & 2 & 0,9 \\
\hline \multirow[t]{2}{*}{ Q9. In your opinion, should people cancel and avoid social events during the outbreak? } & Yes & 198 & 89,6 \\
\hline & No & 23 & 10,4 \\
\hline \multirow[t]{2}{*}{ Q10. In your opinion, should people avoid shaking hands during the outbreak? } & Yes & 207 & 93,7 \\
\hline & No & 14 & 6,3 \\
\hline \multirow{2}{*}{$\begin{array}{l}\text { Q11. In your opinion, should all non-essential stores (other than supermarkets, pharmacies, post offices, gas stations, } \\
\text { etc.) be closed during the pandemic? }\end{array}$} & Yes & 69 & 31,2 \\
\hline & No & 152 & 68,8 \\
\hline \multirow[t]{2}{*}{ Q12. In your opinion, should there be a curfew (except for grocery shopping, work, medical treatment)? } & Yes & 169 & 76,5 \\
\hline & No & 52 & 23,5 \\
\hline \multirow[t]{2}{*}{ Q13. Can the Corona virus infection make your cancer worse? } & Yes & 97 & 43,9 \\
\hline & No & 124 & 56,1 \\
\hline \multirow[t]{4}{*}{ Q14. Where did you get information about COVID-19? } & Radio & 1 & 0,5 \\
\hline & Television & 157 & 71,0 \\
\hline & Internet & 56 & 25,3 \\
\hline & Other & 7 & 3,2 \\
\hline \multirow[t]{5}{*}{ Q15. What are your esStimates of the number of Indonesians infection with Corona virus at this time? } & $<100$ & 5 & 2,3 \\
\hline & $100-1.000$ & 36 & 16,3 \\
\hline & 5000 & 29 & 13,1 \\
\hline & $5000-10.000$ & 48 & 21,7 \\
\hline & $>10.000$ & 103 & 46,6 \\
\hline
\end{tabular}

(219 out of $221,99.1 \%$ ), significantly affecting a quarter of them. A considerable number of patients claimed to be not worried of being infected ( 50 out of $221,22.6 \%$ ), although virtually all of them have adopted the basic preventive measures: self-isolation (210 out of $221,95 \%)$, social distancing (215 out of $221,97.3 \%$ ), hand (219 out of 221 , $99.1 \%$ ) and respiratory hygiene (219 out of $221,99.1 \%$ ). Most agreed that non-essential stores should not be closed during the pandemic ( 152 out of $221,68.8 \%$ ) with a curfew in place (169 out of $221,76.5 \%$ ). The patients are divided approximately in half between those believed coronavirus infections can make their cancer worse $(97$ out of $221,43.9 \%$ ) and those who do not (124 out of 221 ,
$56.1 \%)$. The major sources of information were television (157 out of $221,71 \%$ ) and the internet (56 out of 221 , $25.3 \%$ ) that include mobile communication and social media applications. Evaluation of subjects' knowledge and awareness of the pandemic is presented in Table 2. Eight-one patients admitted to be afraid of being infected by the coronavirus while undergoing chemotherapy, with a minority of them considered stopping chemotherapy or coming to the oncology clinic altogether. Most patients can resume their treatment with no difficulty, while the rest claimed to be affected by harder access to the hospital (42 out of $221,19 \%$ ), treatment postponement (5 out of 221 , $2.3 \%$ ), longer queue (11 out of $221,5.0 \%$ ), and limited 
Table 3. Patient Satisfaction and Perception of Chemotherapy Services during COVID-19 Pandemic

\begin{tabular}{|c|c|c|c|}
\hline Questions & Answer & $\mathrm{n}$ & $\%$ \\
\hline \multirow[t]{3}{*}{ Q16. Are you afraid of being infected with Corona virus while undergoing chemotherapy at the hospital? } & Very afraid & 90 & 40,7 \\
\hline & Somewhat afraid & 89 & 40,3 \\
\hline & Not afraid & 42 & 19,0 \\
\hline \multirow[t]{2}{*}{ Q17. Have you thought of stopping or delaying chemotherapy during the outbreak? } & Yes & 30 & 13,6 \\
\hline & No & 191 & 86,4 \\
\hline \multirow[t]{2}{*}{ Q18. Have you thought of stopping going to the clinic routinely during the outbreak? } & Yes & 28 & 12,7 \\
\hline & No & 193 & 87,3 \\
\hline \multirow{6}{*}{$\begin{array}{l}\text { Q19. Have you ever faced difficulty in getting chemotherapy during the outbreak? If yes, what was the } \\
\text { cause? }\end{array}$} & No difficulty & 154 & 69,7 \\
\hline & Access to hospital & 42 & 19,0 \\
\hline & Treatment postponement & 5 & 2,3 \\
\hline & Longer treatment queue & 11 & 5,0 \\
\hline & Limited hospital workers & 2 & 0,9 \\
\hline & Other & 7 & 3,2 \\
\hline \multirow[t]{2}{*}{ Q20. Did you experience any changes in the chemotherapy service during the outbreak? } & Yes & 80 & 36,2 \\
\hline & No & 141 & 63,8 \\
\hline \multirow{4}{*}{$\begin{array}{l}\text { Q21. In your opinion, is the hospital's safety measures and policy in dealing with the Corona virus } \\
\text { outbreak adequate? }\end{array}$} & Not adequate at all & 1 & 0,5 \\
\hline & Not adequate & 8 & 3,6 \\
\hline & Adequate & 106 & 48,0 \\
\hline & More than adequate & 105 & 47,5 \\
\hline \multirow{4}{*}{$\begin{array}{l}\text { Q22. In your opinion, are the measures and personal protective equipment used by hospital workers } \\
\text { adequate to prevent Corona virus transmission within the hospital? }\end{array}$} & Not adequate at all & 2 & 0,9 \\
\hline & Not adequate & 4 & 1,8 \\
\hline & Adequate & 108 & 48,9 \\
\hline & More than adequate & 107 & 48,4 \\
\hline \multirow{5}{*}{$\begin{array}{l}\text { Q23. How much do you trust the hospital workers (doctors, nurses, administrators, etc.) in maintaining } \\
\text { your safety? }\end{array}$} & Not at all & 1 & 0,5 \\
\hline & A little & 3 & 1,4 \\
\hline & Neutral & 31 & 14,0 \\
\hline & Trust & 11 & 5,0 \\
\hline & Very trusting & 175 & 79,2 \\
\hline \multirow[t]{5}{*}{ Q24. Is there a change in the health care service quality during the outbreak? } & Got very bad & 0 & 0,0 \\
\hline & A little worse & 7 & 3,2 \\
\hline & The same & 113 & 51,1 \\
\hline & Better & 80 & 36,2 \\
\hline & Become much better & 21 & 9,5 \\
\hline \multirow{4}{*}{$\begin{array}{l}\text { Q25. Were you educated about the Corona virus outbreak by the chemotherapy unit workers (doctors, } \\
\text { nurses, ward officers)? }\end{array}$} & Not at all & 76 & 34,4 \\
\hline & A little & 57 & 25,8 \\
\hline & Yes & 68 & 30,8 \\
\hline & A lot & 20 & 9,0 \\
\hline \multirow[t]{5}{*}{ Q26. Where did you get most information about the Corona virus and its relationship to your disease? } & Doctor & 27 & 12,2 \\
\hline & Nurse & 14 & 6,3 \\
\hline & Administrators & 3 & 1,4 \\
\hline & $\begin{array}{l}\text { Hospital announcements } \\
\text { (television, brochures) }\end{array}$ & 113 & 51,1 \\
\hline & Other & 64 & 29,0 \\
\hline \multirow[t]{5}{*}{ Q27. What about the quality of chemotherapy services you received during the outbreak? } & Got very bad & 0 & 0,0 \\
\hline & A little worse & 1 & 0,5 \\
\hline & The same & 124 & 56,1 \\
\hline & Better & 87 & 39,4 \\
\hline & Become much better & 9 & 4,1 \\
\hline
\end{tabular}


Continued Table 3

\begin{tabular}{|c|c|c|c|}
\hline Questions & Answer & $\mathrm{n}$ & $\%$ \\
\hline \multirow[t]{6}{*}{ Q28. What do you think can best improve the quality of chemotherapy services? } & $\begin{array}{l}\text { More PPE worn by } \\
\text { hospital workers }\end{array}$ & 116 & 52,5 \\
\hline & More PPE provided & 30 & 13,6 \\
\hline & $\begin{array}{l}\text { More education from } \\
\text { hospital workers }\end{array}$ & 40 & 18,1 \\
\hline & $\begin{array}{l}\text { Speed up chemotherapy } \\
\text { program }\end{array}$ & 30 & 13,6 \\
\hline & $\begin{array}{l}\text { Stopping or delaying } \\
\text { chemotherapy }\end{array}$ & 1 & 0,5 \\
\hline & Other & 4 & 1,8 \\
\hline \multirow[t]{3}{*}{ Q29. Are you afraid or worried about going to the oncology clinic during the outbreak? } & Yes, very & 56 & 25,3 \\
\hline & A little & 76 & 34,4 \\
\hline & Not afraid/ worried & 89 & 40,3 \\
\hline \multirow{6}{*}{$\begin{array}{l}\text { Q30. In your opinion, what is the most useful way to reduce the level of anxiety or fear when undergoing } \\
\text { chemotherapy during the outbreak? }\end{array}$} & Wearing PPE & 124 & 56,1 \\
\hline & $\begin{array}{l}\text { PPE worn by hospital } \\
\text { workers }\end{array}$ & 47 & 21,3 \\
\hline & $\begin{array}{l}\text { Education and } \\
\text { communication } \\
\text { with hospital workers }\end{array}$ & 27 & 12,2 \\
\hline & $\begin{array}{l}\text { Speed up chemotherapy } \\
\text { program }\end{array}$ & 21 & 9,5 \\
\hline & $\begin{array}{l}\text { Stopping or delaying } \\
\text { chemotherapy }\end{array}$ & 1 & 0,5 \\
\hline & Other & 1 & 0,5 \\
\hline
\end{tabular}

hospital workers ( 2 out of $221,0.9 \%$ ).

The majority of patients trusted the new hospital policies (211 out of $221,95.5 \%$ ), PPE (215 out of 221 , $97.3 \%$ ) and workers (217 out of $221,98.2 \%$ ) for being able to maintain their safety and deliver safe treatment. More than half of the respondents claimed that the quality of both general health care services and chemotherapy remained consistent or even better during the outbreak. Most respondents agreed that more PPE worn by the hospital workers and themselves may improve the quality of chemotherapy service and lower their level of anxiety. Patient perception and satisfaction of oncologic service are presented in Table 3.

\section{Discussion}

The COVID-19 pandemic is an ongoing International concern that created unprecedented media attention and coverage. Never before a disease entity created such interests from the global population across all socioeconomic backgrounds. In Indonesia, the COVID-19 received substantial social publications across all platforms, chiefly the television, internet (including social media, mobile communication app) newspaper (paper and electronic), radio, and mural advertising educating the people with the basic knowledge of coronavirus epidemiology, virology, and prevention [12]. The mass media proved to be a very efficient way of information transfer, as supported by the findings of this survey. Almost all patients (213 out of $221,96.4 \%)$ obtained information about COVID-19 from either the television or the internet. They claimed to be well-informed and successfully practiced social isolation, physical distancing, improved hand, and respiratory hygiene. On the other hand, less than $40 \%$ of patients reported being adequately educated by the chemotherapy unit workers (doctors, nurses, ward officers). In this extraordinary circumstance, the mass media is undoubtedly faster and more efficient compared to the direct doctor-to-patient education system.

However, the deficiency in doctor-to-patient education should be addressed considering the media does not broadcast in-depth knowledge such as the relationship between COVID-19, cancer, and chemotherapy.

Only $27(12.2 \%)$ patients in our study claimed to be educated their physicians in regard to this matter. Access and comprehension of advanced medical information are limited to healthcare professionals. Extensive media coverage of the coronavirus outbreak may also be counterproductive by creating exacerbated public fear, panic, and stress [13]. Thus physicians play a major role in patient education by being able to practice evidence-based medicine, filter fallacious information, and control patient apprehension. In short, it is advisable for policymakers to capitalize on effective educational platforms (e.g. hospital televised infomercial, hospital mobile app), without abandoning the physician's pivotal role in direct patient education.

Following the declaration of COVID-19 as a global emergency, the Indonesian Government created the COVID-19 Response Acceleration Task Force (CRATF) in an effort to accelerate the mitigation of coronavirus disease. Coordinated by the Indonesian National Board for Disaster Management, Ministry of Health, National Police and Armed force, the task force published a series of guidelines for all sectors aiming to manage the outbreak [14]. The guideline for health care sector was formulated 
Table 4. COVID-19 Patient Categorization and Initial Approach

\begin{tabular}{|c|c|c|c|c|c|c|}
\hline No & $\begin{array}{l}\text { Fever / history } \\
\text { of fever }\end{array}$ & $\begin{array}{l}\text { Respiratory } \\
\text { symptoms }^{\text {a }}\end{array}$ & $\begin{array}{l}\text { Transmission } \\
\text { region }^{\mathrm{b}}\end{array}$ & $\begin{array}{l}\text { Close contact } \\
\text { with } \\
\text { confirmed } \\
\text { case }\end{array}$ & $\begin{array}{l}\text { Patient } \\
\text { category }^{\mathrm{c}}\end{array}$ & Management \\
\hline 1 & + & + & + & & PUS & $\mathrm{CBC}, \mathrm{WBCD}, \mathrm{CXR}, \mathrm{NPS}$ \\
\hline 2 & \pm & \pm & & + & PUS & \\
\hline 3 & + & $+($ severe $)$ & & & PUS & Hospital admission (isolation ward), NPS \\
\hline 4 & \pm & \pm & + & & PUM & $>60$ yo: $\mathrm{CBC}, \mathrm{WBCD}, \mathrm{CXR}, \mathrm{NPS}$ \\
\hline 5 & & + & & + & PUM & $\begin{array}{l}<60 \text { yo with comorbidities: CBC, WBCD, CXR,NPS } \\
<60 \text { yo without comorbidities: NPS }\end{array}$ \\
\hline 6 & & & & + & PWS & NPS \\
\hline 7 & & & + & & & Education and self isolation \\
\hline
\end{tabular}

${ }^{a}$ Cough/dyspnea/sore throat/rhinorrhea, ${ }^{b}$ person from transmission region as defined by the Indonesian COVID-19 Task Force [3], ${ }^{\mathrm{c}}$ Since 14 July 2020 the Indonesian COVID-19 patient category system followed the case definitions as defined by the WHO [24]. \pm at least one positive; PUS, patient under surveillance; PUM, person under monitoring; PWS, person without symptom; CBC, complete blood count; WBCD, white blood cell differential; CXR, chest x-ray; NPS, 2 consecutive days of nasopharyngeal swabs for RT-PCR assays.

from collective information from several of the Nation's medical specialist associations [15]. Hospitals are advised to follow this guideline, however, it can be adjusted based on the available human resources and medical facilities of each region. As a tertiary referral hospital, our oncology center adhered to the local hospital guideline that is in concordance with the COVID-19 guideline published by the National Task Force.

Online reservation for clinical follow-up or chemotherapy was made mandatory since the pandemic. All patients were instructed to come at most 15 minutes before the designated time and instructed to directly go home after they are done. Before entering the building, all patients were screened by trained personnel using the COVID-19 early warning score (EWS) screening tool [16] and classified into one of the four patient categories based on their relation with COVID-19: person without symptom (PWS), person under monitoring (PUM), patient under surveillance (PUS), and confirmed case. Case definitions and initial approaches are summarized in Table 4.

Only those who are not suspected of COVID-19 were allowed inside to continue their treatment otherwise, the patient is directed to a dedicated COVID-19 management area within the hospital complex. All hospital staffs within the premise continuously enforce facemask usage and physical distancing. Such precautionary measures would have been a major inconvenience for patients in the preCOVID era by creating longer queues and discomfort. Anxiety is a common problem in cancer patients and will negatively impact their quality of life, treatment satisfaction, and outcome [17]. The fear of contracting coronavirus aggravates this problem, as shown in our study that $81 \%$ of the patients were afraid of being infected while undergoing chemotherapy. Some of them even thought of stopping chemotherapy (30 out of 221, $13.6 \%$ ) or coming to the clinic for follow-up altogether ( 28 out of $221,12.7 \%$ ). Although COVID-19 preventive measures are not $100 \%$ effective in preventing disease transmission, we think its application is detrimental for patients by creating a "sense of security" reducing their level of anxiety and fear. Almost all respondents trusted the hospital's policy in handling COVID-19 and put confidence in the hospital staff for maintaining their safety. Based on this survey, PPE worn by the healthcare personnel and patient is the major anxiety-reducing factor while undergoing chemotherapy. The level of PPE worn by hospital personnel was deemed adequate by $97.3 \%$ of respondents. However interestingly, half of them think that more PPE worn by hospital workers can further improve the quality of service. Our institution was able to maintain the quality of chemotherapy service during the pandemic. About half of the respondents (113 out of 221, $51.1 \%$ ) think the quality of service remains the same and even improved during the pandemic. Most patients in our study (154 out of $221,69.7 \%$ ) were able to resume their chemotherapy normally since the pandemic. Some patients (42 out of $221,19 \%$ ) patients had problems coming to the hospital from neighboring cities because of the inter-city travel bans imposed by the government from late April until early June.

The main dilemma for continuing chemotherapy during the crisis is the potential infection of COVID-19. Limited data from the Chinese population suggest cancer patients who contracted COVID-19 suffered from higher rates of severe events and mortality compared to their counterparts [18-19]. However, a current systematic review does not support interruption of chemotherapy or immunotherapy for cancer patients and does not recommend withholding anticancer therapy for those who do not have COVID-19 [20]. One prospective cohort study suggests that mortality from COVID-19 in cancer patients is more driven by age, gender, and comorbidities [21]. Solid data is lacking to draw any conclusion in the potential harm from interrupting chemotherapy versus the benefits of possibly preventing COVID-19 infection. In this light, many clinical resources have recently been published guidelines for health care professionals on the proper recommendations to deliver safe and effective oncologic services.

Major guidelines generally advise the approach should be individualized based on the patient's level of priority. The American Society of Clinical Oncology (ASCO) advised clinical decision to be based on cancer curability, risk of recurrence with treatment modification 
or interruption, the number of cycles already completed, and patient's tolerance to treatment. Chemotherapy recommendations set forth by ASCO include stopping chemotherapy as an option for those in deep remission receiving maintenance therapy or in cases where the clinical benefit of adjuvant chemotherapy is expected to be small, start oral chemotherapy or home infusion, alter treatment schedule for fewer visits, and to be selective in using drugs that inhibit B cells such as anti-CD20 monoclonal antibodies [9]. The European Society for Medical Oncology (ESMO) similarly recommends classifying and treating cancer patients according to their level of priority. The proposed cancer patient prioritizations proposed by the ESMO-Magnitude of Clinical Benefits (ESMO-MCBS) are [1] high priority patients who are in an immediate life-threatening, a clinically unstable disease where treatment is ideally not delayed, [2] medium priority patients in a non-critical situation that treatment delay for more than 6 weeks may adversely affect the overall clinical outcome, [3] low priority patients in a condition that is stable enough that treatment can be delayed for the duration of COVID-19 pandemic [6].

A national guideline published by The Indonesian Society of Surgical Oncology (ISSO) is in accord with several International guidelines (10). For example prioritization, treatment, and triage of breast cancer patients is consistent with the recommendations made by the American Society of Breast Surgeons (ASBrS) [22]. Thyroid cancer management is based on the British Association of Endocrine and Thyroid Surgeons (BAETS) statement [23]. Management of melanoma and sarcoma adhered to the guidelines published by ESMO [6]. In our institution, the decision whether or not to postpone cancer treatment were made on a patient-by-patient basis by the oncologists' clinical judgment. Current local hospital guideline does not dictate specifically in regards to this matter. To which practice guidelines each oncologist follow was not recorded and is beyond the scope of this study. Only $5(2.3 \%)$ patients experienced treatment postponement during the course of this survey that suggests treatment interruption is uncommon. The oncology working groups to meet and reach a conclusion on which guideline that they are going to follow to maintain service quality.

The inherent limitation of this study is the small size convenience sampling that is not translatable to the general population. Since the majority of cancer patients in our hospital were breast, head, and neck cancers, there may be selection bias caused by venue selection to distribute the questionnaires. Since data collection was performed in a cross-sectional fashion the causal relationship between the variables cannot be made.

In conclusion, the COVID-19 pandemic significantly alters all aspects of life, including health care services. Changes in hospital treatment policies in an attempt to manage disease transmission may inadvertently impose a greater level of anxiety and unnecessary treatment interruption for cancer patients. The effectiveness of the media in spreading general knowledge about of COVID-19 is undeniable. However, information sharing through this platform may backfire by being misinterpreted and creates exaggerated fear. Findings from this study suggest that the majority of Indonesian cancer patients in Central Java possess adequate knowledge and successfully practiced appropriate preventive measures towards the COVID-19 pandemic. They expressed a positive attitude towards the changes in hospital policies and were generally happy with the consistency of chemotherapy services during the pandemic. So far, alterations in the treatment program were individualized for each cancer type by the oncologists in accordance with their respective specialist association guidelines. Definitive data on the risks and benefits of altering chemotherapy for cancer patients during COVID-19 remains to be elucidated and will require longer prospective observations from cases all around the world.

\section{Funding \\ No funding}

\section{References}

1. PUSDATIN. Kementrian Kesehatan Indonesia. Dashboard Kasus COVID-19 di Indonesia: Indonesian Ministry of Health; 2020 [updated 202006 May; cited 202007 May]. Available from: https://www.kemkes.go.id/article/ view/20031900002/Dashboard-Data-Kasus-COVID-19di-Indonesia.html.

2. WHO. Novel Coronavirus (2019-nCoV) Situation report -2: World Health Organization; 2020 [updated 202021 January cited 202007 May]. Available from: https:// www.who.int/docs/default-source/coronaviruse/situationreports/20200122-sitrep-2-2019-ncov.pdf.

3. Peta Sebaran [Internet]. Gugus Tugas Percepatan Penanganan COVID-19. 2020 [cited 15 July 2020]. Available from: https://covid19.go.id/peta-sebaran..

4. Yu J, Ouyang W, Chua MLK, Xie C. SARS-CoV-2 Transmission in Patients With Cancer at a Tertiary Care Hospital in Wuhan, China. JAMA Oncology. 202007 01;6(7):1108. https://doi.org/10.1001/jamaoncol.2020.0980

5. ACS. COVID-19: Elective Case Traige Guidelines for Surgical Care: American Cancer Society; 2020 [updated 202024 March; cited 202007 May]. Available from: https://www. facs.org/covid-19/clinical-guidance/elective-case..

6. ESMO. Cancer Patient Management During the COVID-19 Pandemic: European Society for Medical Oncology; 2020 [updated 202007 May; cited 202007 May]. Available from: https://www.esmo.org/guidelines/cancer-patientmanagement-during-the-covid-19-pandemic..

7. CDC. Strategic Priority Infection Prevention and Control Activities for Non-US Healthcare Settings: Centers for Disease Control and Prevention; 2020 [updated 202006 April; cited 202007 May]. Available from: https://www. cdc.gov/coronavirus/2019-ncov/hcp/non-us-settings/ipchealthcare-facilities-non-us.html.

8. PORI. Pedoman Pelayanan Onkologi Radiasi pada Pandemi COVID-19: Indonesian Radiation Oncologist Association; 2020 [updated 2020 April; cited 202007 May]. Available from: https://covid19.idionline.org/wp-content/ uploads/2020/04/8.PORI_.pdf.

9. ASCO. ASCO Special Report: A Guide to Cancer Care Delivery During The COVID-19 Pandemic: American Society of Clinical Oncology; 2020 [updated 19 May 2020. 
Available from: https://www.asco.org/sites/new-www. asco.org/files/content-files/2020-ASCO-Guide-CancerCOVID19.pdf.

10. PERABOI. Panduan Pelayanan Bedah Onkologi selama Pandemi COVID-19 di Indonesia [pdf]. Jakarta: Indonesian Association of Surgical Oncologist; 2020 [updated 25 April 2020; cited 202007 May]. Available from: http://www. peraboi.com/.

11. Torales J, O'Higgins M, Castaldelli-Maia JM, Ventriglio A. The outbreak of COVID-19 coronavirus and its impact on global mental health. International Journal of Social Psychiatry. 202003 31;66(4):317-320. https://doi. org/10.1177/0020764020915212

12. IMH. Kumpulan Publikasi Media Sosial COVID-19 [Internet database]. Indonesian Ministry of Health; 2020 [updated 26 May 2020. Available from: http://promkes.kemkes.go.id/ kumpulan-publikasi-media-sosial-covid-19.

13. Roy D, Tripathy S, Kar SK, Sharma N, Verma SK, Kaushal V. Study of knowledge, attitude, anxiety \& perceived mental healthcare need in Indian population during COVID-19 pandemic. Asian Journal of Psychiatry. 2020 06;51:102083. https://doi.org/10.1016/j.ajp.2020.102083

14. CRATF. Pedoman Tatalaksana COVID-19 Indonesia: Gugus Tugas Percepatan Penanganan COVID-19; 2020 . [Available from: https://covid19.go.id/p/protokol/pedomantatalaksana-covid-19.

15. CRATF. Guidelines for Prompt Medical and Public Health Management of COVID-19 in Indonesia: Gugus Tugas Percepatan Penanganan COVID-19; 2020 [cited 2020 15 July]. Available from: https://covid19.kemkes.go.id/ download/Pedoman Penanganan Cepat Medis dan Kesehatan_Masyarakat_COVID-19_di_Indonesia.pdf.pdf..

16. Song C, Xu J, He J, Lu Y. COVID-19 early warning score: a multi-parameter screening tool to identify highly suspected patients. medRxiv. 2020:2020.03.05.20031906

17. Truong DV, Bui QTT, Nguyen DT, Moore J. Anxiety Among Inpatients With Cancer: Findings From a Hospital-Based Cross-Sectional Study in Vietnam. Cancer Control. 2019 01;26(1):107327481986464. https://doi. org/10.1177/1073274819864641

18. Liang W, Guan W, Chen R, Wang W, Li J, Xu K, Li C, Ai $\mathrm{Q}, \mathrm{Lu} \mathrm{W}$, Liang H, Li S, He J. Cancer patients in SARSCoV-2 infection: a nationwide analysis in China. The Lancet Oncology. 2020 03;21(3):335-337. https://doi.org/10.1016/ s1470-2045(20)30096-6

19. Zhang L, Zhu F, Xie L, Wang C, Wang J, Chen R, Jia P, Guan H, Peng L, Chen Y, Peng P, Zhang P, Chu Q, Shen Q, Wang Y, Xu S, Zhao J, Zhou M. Clinical characteristics of COVID-19-infected cancer patients: a retrospective case study in three hospitals within Wuhan, China. Annals of Oncology. 2020 07;31(7):894-901. https://doi.org/10.1016/j. annonc.2020.03.296

20. Russell B, Moss C, George G, Santaolalla A, Cope A, Papa S, Van Hemelrijck M. Associations between immune-suppressive and stimulating drugs and novel COVID-19-a systematic review of current evidence. ecancermedicalscience. 202003 27;14. https://doi. org/10.3332/ecancer.2020.1022

21. Lee LYW, Cazier JB, Starkey T, Turnbull CD, Kerr R, Middleton G. COVID-19 mortality in patients with cancer on chemotherapy or other anticancer treatments: a prospective cohort study. The Lancet. 2020 06;395(10241):1919-1926. https://doi.org/10.1016/s0140-6736(20)31173-9

22. Dietz JR, Moran MS, Isakoff SJ, Kurtzman SH, Willey SC, Burstein HJ, Bleicher RJ, Lyons JA, Sarantou T, Baron PL, Stevens RE, Boolbol SK, Anderson BO, Shulman LN,
Gradishar WJ, Monticciolo DL, Plecha DM, Nelson H, Yao KA. Recommendations for prioritization, treatment, and triage of breast cancer patients during the COVID-19 pandemic. the COVID-19 pandemic breast cancer consortium. Breast Cancer Research and Treatment. 2020 04 24;181(3):487-497. https://doi.org/10.1007/s10549-02005644-Z

23. BAETS. BAETS statement on COVID-19 and Thyroid Cancer Services: British Association of Endocrine and Thyroid Surgeons; 2020 [cited 202015 July]. Available from: https://www.entuk.org/sites/default/files/BAETS $\% 20$ Statement $\% 20$ Thyroid $\% 20$ Cancer $\% 20 \% 20$ - $\% 20$ Covid $\% 20$ $\% 281 \% 29$.pdf.

24. WHO. Global surveillance for COVID-19 caused by human infection with COVID-19 virus Interim guidance 2020 [cited 202015 July]. Available from: https://www.who. int/publications/i/item/global-surveillance-for-humaninfection-with-novel-coronavirus-(2019-ncov).

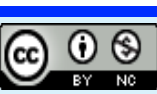

This work is licensed under a Creative Commons AttributionNon Commercial 4.0 International License. 